\title{
MONITORING NILAI KRITIS TEKANAN SISTOLIK DAN DIASTOLIK PADA ASUHAN KEPERAWATAN GAGAL GINJAL KRONIK YANG DILAKUKAN HEMODIALISIS JENIS ARTERIOVENA SHUNT CIMINO DAN AKSES FEMORAL CEPHALICA
}

\author{
Martono \\ Kementerian Kesehatan Politeknik Kesehatan Surakarta Jurusan Keperawatan
}

\begin{abstract}
Systolic Pressure, Diastolic, Hemodialysis. Renal function at a more serious stage of the remnants of the metabolism could not be removed from the body, besides that however the kidneys can no longer changed $\mathrm{K} / \mathrm{H}$ for $\mathrm{Na}$ that resulted in an increase in the amount of potassium that machine that later can be triggered the interruption the heart. Hemodialysis is one of the alternative solutions that can be done when the kidneys experiencing the inability to mengekresikan debris from the remnants of the metabolism of the body. This research aims to clarify the picture changes critical value systolic pressure and diastolic pressure that done arteriovena cimino shunt type of hemodialysis and femoral access cephalica nursing nursery on chronic renal failure. This is the explanatory research design research with cross sectional approach. A sample of this research is to patients with chronic renal failure undergoing hemodialysis which numbered 44 samples with sampling techniques using purposive sampling. This research statistics tests using diskriptif test with the level of the significance of $95 \%$. The results of the study showed that the patients who performed hemodialysis aged candidates are age $\geq 51$ about 59 percent and the age of the youngest 29 years and oldest 77 years, which dominated gender male. 57 percent patients who do good hemodialysis AV Shunt or dialysis access Cephalica Femoral most no change in systolic pressure and diastolic pressure or settled.
\end{abstract}

Keywords: Systolic Pressure, Diastolic Pressure, Hemodialysis

Abstrak: Tekanan Sistolik, Diastolik, Hemodialisis. Gangguan fungsi ginjal pada stadium yang lebih berat, sisa-sisa metabolisme tidak dapat dikeluarkan dari dalam tubuh, selain itu tubulus ginjal tidak dapat lagi menukar $\mathrm{K}^{+} / \mathrm{H}^{+}$untuk $\mathrm{Na}^{+}$sehingga mengakibatkan peningkatan jumlah kalium yang berat yang nantinya dapat memicu terjadinya henti jantung. Hemodialisis merupakan salah satu solusi alternative yang dapat dilakukan bila ginjal mengalami ketidakmampuan untuk mengekresikan sampah dari sisa-sisa metabolisme dari dalam tubuh. Penelitian ini bertujuan untuk menjelaskan gambaran perubahan nilai kritis tekanan sistolik dan diastolik yang dilakukan hemodialisis jenis arteriovena shunt cimino dan akses femoral cephalica pada asuhan keperawatan gagal ginjal kronik. Disain penelitian ini adalah explanatory research dengan pendekatan cross sectional. Penelitian ini dilakukan pada pasien gagal ginjal kronik yang mengalami hemodialisis yang berjumlah 44 sampel dengan teknik pengambilan sampel menggunakan purposive sampling. Uji statistik penelitian ini menggunakan uji diskriptif dengan tingkat signifikansi $95 \%$. Hasil penelitian menunjukkan bahwa pasien yang dilakukan hemodialisis rentang usia terbanyak adalah 
usia $\geq 51$ sebesar $59 \%$ dan usia termuda 29 tahun dan tertua 77 tahun, yang didominasi jenis kelamin laki-laki.57\% Pasien yang dilakukan hemodialisis baik AV Shunt maupun akses Dialisis Cephalica Femoral sebagian besar tidak ada perubahan dalam tekanan sistolik dan diastolik atau menetap.

Kata Kunci: Tekanan Sistolik, Diastolik, Hemodialisis

\section{PENDAHULUAN}

Salah satu fungsi Ginjal adalah menjaga keseimbangan cairan, elektrolit dan asam basa dalam tubuh, sehingga bila terjadi gangguan fungsi ginjal akan menyebabkan gangguan keseimbangan cairan, elektrolit dan asam basa. Gangguan fungsi ginjal pada stadium yang lebih berat, sisa-sisa metabolisme tidak dapat dikeluarkan dari dalam tubuh, selain itu tubulus ginjal tidak dapat lagi menukar $\mathrm{K}^{+} / \mathrm{H}^{+}$untuk $\mathrm{Na}^{+}$sehingga mengakibatkan peningkatan jumlah Kalium yang berat yang nantinya dapat memicu terjadinya henti jantung.

Perhimpunan Nefrologi Indonesia/ Pernefri, 2015) melaporkan bahwa angka kejadian pasien yang memiliki diagnose utama kelainan ginjal yang dilakukan dialisis pada tahun 2015 sebagian besar adalah Gagal Ginjal Kronik sebesar 89\%, Gagal Ginjal Akut sebanyak 7\%, dan pasien Gagal Ginjal Akut pada Gagal Ginjal Kronik sebanyak $4 \%$. Lebih lanjut dijelaskan bahwa penyebab kematian dari 1243 pasien yang dilakukan hemodialisis sebagian besar adalah Kardiovaskuler sebesar $44 \%$, Serebrovaskuler $8 \%$, tidak diketahui penyebabnya sebesar $23 \%$, sepsis sebesar $16 \%$, perdarahan saluran pencernaan seesar 3\%, dan penyebab lain $6 \%$.

Hemodialisa merupakan salah satu solusi alternative yang dapat dilakukan bila ginjal mengalami ketidakmampuan untuk mengekresikan sampah dari sisasisa metabolisme dari dalam tubuh. Salah satu keuntungan tindakan hemodialisis adalah darah yang mengandung hasil sisasisa metabolisme dengan konsentrasi yang tinggi di lewatkan pada membran semipermeabel yang terdapat dalam dialiser. Sisa metabolisme tubuh seperti ureum dan kreatinin dapat disaring melalui proses difusi, sehingga terpisah dari darah bersih dan kadar ureum kreatinin akan menurun. Keadaan tersebut juga dapat mengembalikan status fisiologi fungsi ginjal menjadi lebih baik dengan mempertahankan kemampuan fungsi ginjal untuk mengeksresikan sisa produk nitrogen, toksin dan obat-obatan, mampu untuk menangani beban air dan elektrolit dengan efisien, keseimbangan asam basa, dan mampu memproduksi eritropoetin. Kalau mesin ini terganggu maka tubuh akan keracunan dari sampah hasil metabolisme tubuh, sehingga akan menimbulkan bentuk penyakit akibat bagian-bagian tubuh terganggu oleh menumpuknya racun (Syamsir \& Broto, 2007).

Monitoring nilai kritis tekanan darah merupakan indikator paling penting untuk mengetahui secara dini tanda-tanda pasien mengalami syok, hipotensi atau mengalami hipertensi. Setelah dilakukan dialisis biasanya ditemukan penurunan dan kenaikan yang signifikan dari tekanan darah pasien, rata-rata sekitar 10-30 $\mathrm{mmHg}$ dari hasil pengukuran sebelum dilakukan dialisis. Pengukuran tekanan darah ini biasanya dilakukan pada awal 
sebelum, saat proses dan sesudah akhir dilakukan dialisis.

Berdasarkan hasil survey yang dilakukan terhadap 30 pasien yang dilakukan dialisis dari 15 orang yang menggunakan akses cimino 7 orang mengalami kenaikan tekanan darah, 3 orang tidak ada perubahan tekanan darah, 5 orang mengalami penurunan tekanan darah. Untuk 12 orang yang dilakukan hemodialisis menggunakan akses femoral 4 orang mengalami kenaikan tekanan darah, 2 orang tetap, an 6 orang mengalami penurunan. Sedangkan 3 orang yang yang dilakukan hemodialisis akses menggunakan double lumen semuanya mengalami penurunan tekanan darah. Selain itu, dengan adanya keterbatasan tenaga kesehatan di Ruang haemodialisa Rumah Sakit Dr Moewardi Surakarta pengukuran tekanan darah hanya dilakukan pada awal sebelum dialisis saja, dan pada akhir dialisis beberapa pasien tidak diukur kembali tekanan darahnya, sehingga tidak diketahui apakah ada kenaikan/ penurunan tekanan darah. Berdasarkan uraian diatas, perlu dilakukan kajian yang lebih mendalam tentang deteksi dini nilai kritis tekanan sistolik dan diastolik pada asuhan keperawatan gagal ginjal kronik yang dilakukan dialisis.

\section{METODE PENELITIAN}

Penelitian ini dilakukan dengan rancangan explanatory research dengan pendekatan cross sectional. Disain ini dilakukan untuk menjelaskan gambaran tindakan dialisis yang dilakukan pemasangan arteriovena shunt cimino dan akses femoral cephalica terhadap perubahan nilai kritis tekanan sistolik dan diastolik pada asuhan keperawatan gagal ginjal kronik yang dilakukan dialisis. Populasi penelitian ini adalah semua pasien Gagal Ginjal Kronik yang dilakukan dialisis terpasang akses vaskuler arteriovena shunt cimino dan akses femoral cephalica yang dirawat di unit Hemodialisa Rumah Sakit Umum dr. Moewardi Surakarta yang berjumlah 44 sampel dengan teknik pengambilan sampel menggunakan purposive sampling. Uji statistik yang digunakan dalam penelitian ini adalah uji diskriptif dengan tingkat signifikansi yang dipahami $95 \%$.

\section{HASIL PENELITIAN}

Sebaran Umur Responden

Dari 44 sampel yang dilakukan haemodialisa dapat dijelaskan bahwa sebagian besar mempunyai umur $\geq 51$ tahun sebesar 26 orang (59\%), umur 41 sampai 50 tahun sebesar 9 orang $(20.5 \%)$, 31 sampai 40 tahun sebesar 8 orang $(18.2 \%)$ dan yang berumur $\leq 30$ tahun sebanyak 1 orang $(2.3 \%)$. Sebaran umur dijelaskan pada gambar 1 .

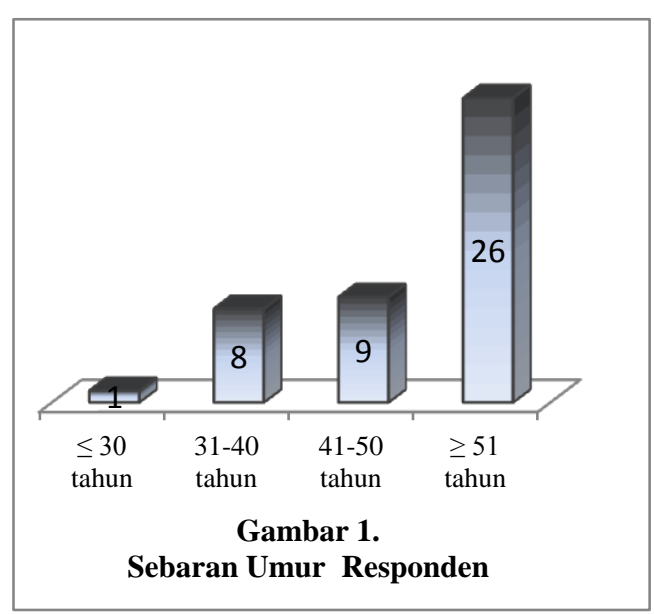

Sebaran Jenis Kelamin Responden

Dari 44 sampel yang dilakukan haemodialisa dapat dijelaskan bahwa sebagian besar jenis kelamin laki-laki sebesar 25 orang $(57 \%)$, dan perempuan sebesar 19 orang (43\%). Sebaran jenis kelamin dijelaskan pada gambar 2 . 


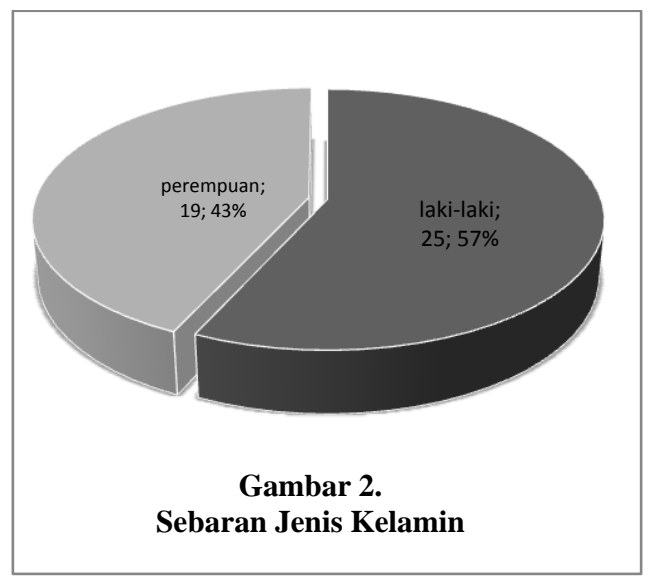

Sebaran Tingkat Pendidikan Responden

Dari 44 sampel yang dilakukan haemodialisa dapat dijelaskan bahwa sebagian besar tingkat pendidikan SD sebesar 19 orang (43.2\%), SMA sebesar 15 orang $(34.1 \%)$, SMP sebesar 7 orang (15.9\%) dan peguruan tinggi sebesar 3 orang (6.8\%). Sebaran pendidikan dijelaskan pada gambar 3 .

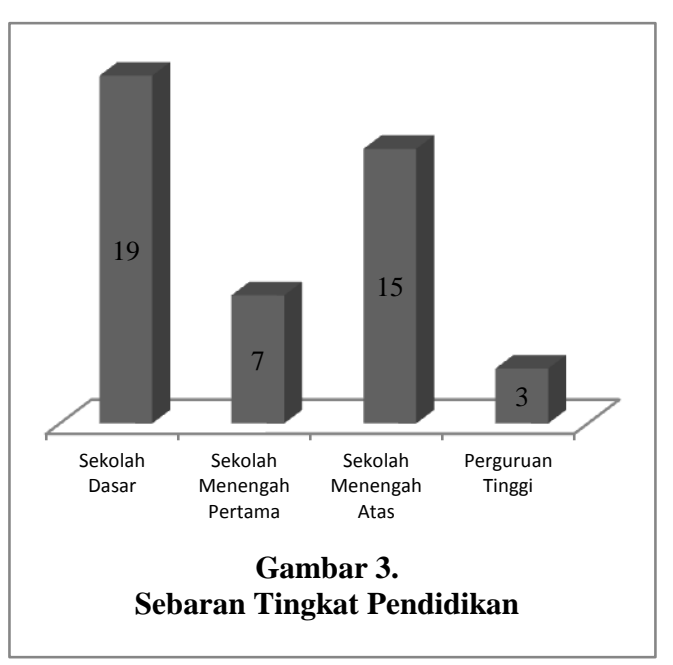

Sebaran Jenis Haemodialisa

Dari 44 sampel yang dilakukan haemodialisa dapat dijelaskan bahwa sebaran jenis haemodialisa AV Shunt maupun akses Femoral Cephalica masing-masing sebesar 22 orang $(50 \%)$.

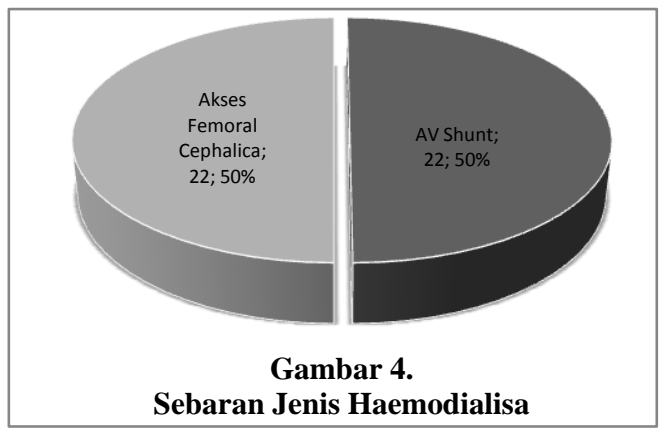

Sebaran klasifikasi tekanan sistolik dan diastolik yang dilakukan dialisis

Dari 44 sampel yang dibagi menjadi 22 kelompok sampel yang dilakukan dialisis AV Shunt dijelaskan bahwa sebaran tekanan sistolik sebelum dilakukan dialisis sebagian besar dengan kategori hipertensi parah dan hipertensi stadium II masing-masing sebanyak 7 orang $(31.8 \%)$, kategori pra hipertensi sebanyak 5 orang $(22.8 \%)$, hipertensi stadium I sebanyak 2 orang $(9.1 \%)$, dan normal sebanyak 1 orang (4.5\%). Lebih lanjut dijelaskan bahwa klasifikasi tekanan diastolik pra dialisis sebagian besar dikategorikan hipertensi stadium II sebanyak 12 orang (54.5\%), normal sebanyak 5 orang (22.7\%), pra hipertensi sebanyak 4 orang (18.2\%), danrendah 1 orang $(4.6 \%)$. Sedangkan tekanan sistolik setelah dilakukan dialisis sebagian besar normal sebanyak 5 orang $(22.7 \%)$, pra hipertensi, hipertensi parah, hipertensi stadium I, dan II masing-masing sebesar 4 orang (18.2\%). Tekanan diastolik setelah dilakukan dialisis sebagian besar normal dan pra hipertensi masing-masing sebesar 6 orang (27.3\%), hipertensi stadim II sebanyak 5 orang (22.7\%), hipertensi stadium I dan rendah sebesar 2 orang $(9.1 \%)$, dan 1 orang $(4.5 \%)$ mengalami hipertensi parah. Sebaran klasifikasi tekanan sistolik dan diastolik pra dan post dialisis AV Shunt dijelaskan pada gambar 5. Sedangkan 22 kelompok 
sampel yang dilakukan dialisis akses cephalic femoral dapat dijelaskan bahwa sebagian besar mengalami hipertensi parah sebanyak 10 orang $(45.5 \%)$, hipertensi stadium II sebanyak 6 orang (27.3\%), hipertensi stadium I sebanyak 4 orang $(18.3 \%)$, dan pra hipertensi sebanyak 2 orang $(9.1 \%)$.

Lebih lanjut dijelaskan tekanan sistolik setelah dilakukan dialisis cephalic femoral sebagian besar hipertensi parah sebesar 7 orang $(31.8 \%)$, pra hipertensi sebesar 6 orang (27.3\%), normal sebesar 4 orang $(18.2 \%)$, hipertensi stadium II sebanyak 3 orang (13.6\%), hipertensi stadium I dan rendah masing-masing sebesar 1 orang (4.5\%). Tekanan diastolik sebelum dilakukan dialisis akses cephalic femoral sebagian besar mengalami pra hipertensi sebesar 7 orang (31.8\%), hipertensi stadium I sebesar 6 orang (27.3\%), hipertensi stadium II sebanyak 4 orang $(18.2 \%)$, normal sebanyak 3 orang (13.6\%), dan hipertensi parah sebanyak 2 orang (9.1\%). Tekanan diastolik setelah dilakukan dialisis akses cephalic femoral sebagian besar hipertensi stadium II dan pra hipertensi masing-masing sebesar 7 orang (31.8\%), hipertensi stadium I dan normal masingmasing sebesar 4 orang (18.2\%). Sebaran klasifikasi tekanan sistolik dan diastolik pra dan post dialisis cephalic femoral dapat dijelaskan pada gambar 6 .

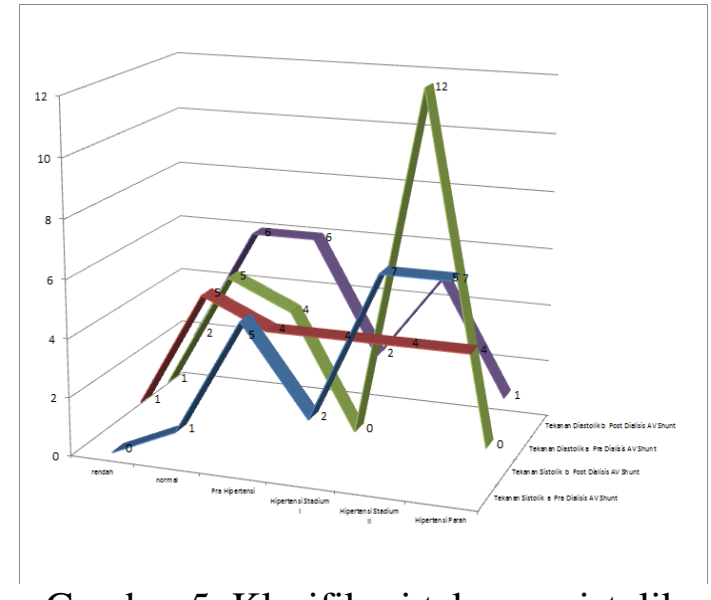

Gambar 5. Klasifikasi tekanan sistolik dan diastolik Dialisis AV Shunt

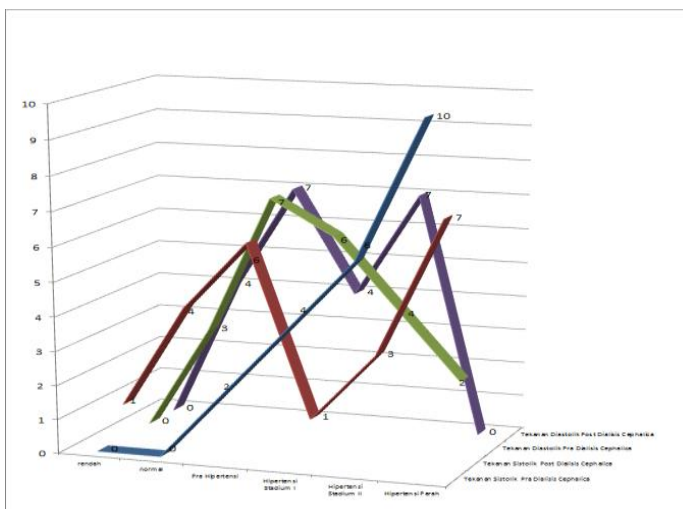

Gambar 6. Klasifikasi tekanan sistolik dan diastolik Dialisis Cephalica Femoral

\section{Tekanan darah pasca Hemodialisis $A V$ Shunt dan Cephalica Femoral}

Perubahan tekanan sistolik dan diastolik pada kelompok sampel berjumlah 22 orang yang dilakukan haemodialisis $A V$ Shunt sebagian besar tekanan sistolik dan diastolik dalam kategori menetap dan menurun masingmasing sebesar 8 orang $(36.4 \%)$, dan meningkat sebesar 6 orang (27.3\%). Sedangkan 22 orang kelompok sampel orang yang dilakukan haemodialisis Dialisis Cephalica Femoral sebagian besar tekanan sistolik dan diastolik dalam kategori menetap sebesar 25 orang 
(56.8\%), kategori meningkat sebesar 14 orang $(31.8 \%)$, dan kategori menurun sebesar 5 orang $(11.4 \%)$. Sebaran jenis dialisis dijelaskan pada gambar 7 .

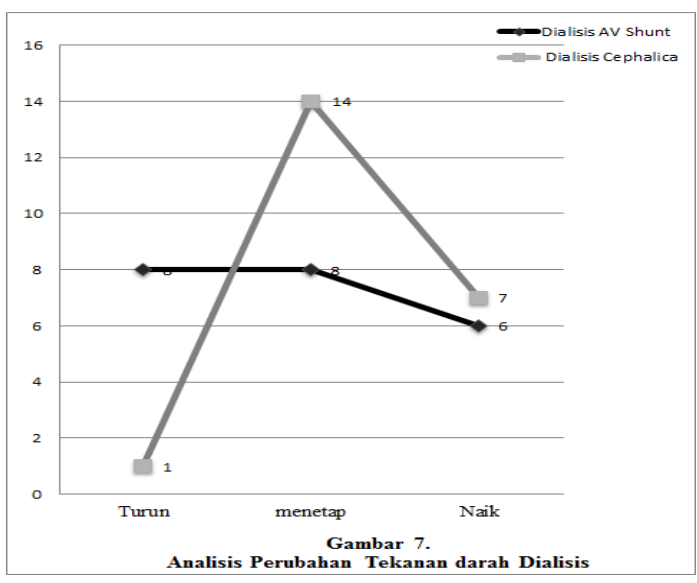

\section{PEMBAHASAN}

Umur

Sebaran umur pada penelitian ini diperoleh usia termuda 29 tahun dan tertua 77 tahun. Rentang usia terbanyak didapatkan pada usia $\geq 51$ tahun yaitu sebesar 59\%. Hal tersebut sesuai dengan karakteristik pada pasien dengan penyakit gagal ginjal yang dilakukan haemodialisis di Indonesia, sebagaimana yang telah dilaporkan Indonesia Renal Registry (IRR) tahun 2011 yaitu sebanyak $89 \%$ berumur 35-70 tahun dengan kelompok umur terbanyak 45-54 tahun yaitu $27 \%$. Hal yang sama juga disampaikan oleh Hanie, Fadli, dan Rudy, (2014) yang menjelaskan bahwa pasien yang dilakukan hemodialisis umur penderita berkisar 22-75 tahun dengan rata-rata 52,39 $\pm 10,39$ tahun dan terbanyak umur 50-59 tahun yaitu sebesar $50,86 \%$. Hal ini serupa dari penelitian sebelumnya yang dilakukan Ferry, Parlindungan, Ginova, Hamzah, (2014) yang menjelaskan bahwa subyek yang dilakukan hemodialisis sebagian besar dengan rerata usia 54.8 tahun.
Salah satu faktor yang dapat mempengaruhi penurunan fungsi ginjal seseorang salah satunya adalah faktor usia. Semakin bertambahnya umur seseorang akan mempengaruhi fisiologis organ ginjal. Hal ini sesuai dengan pendapat (Smeltzer \& Bare, 2002) yang menjelaskan bahwa, usia merupakan faktor yang dapat mempengaruhi kesehatan seseorang. Lebih lanjut dijelaskan bahwa semakin bertambahnya usia, maka organ ginjal mengalami penurunan massa ginjal sebagai akibat kehilangan beberapa nefron sehingga terjadi penurunan laju filtrat glomerulus.

\section{Jenis Kelamin}

Sebaran karakteristik jenis kelamin pada penelitian ini sebagian besar laki-laki sebesar $57 \%$, dan perempuan sebesar 43\%. Karakteristik ini hampir sama dengan data dari IRR, (2011) yang malaporkan bahwa di Indonesia, dari 6951 pasien yang dilakukan hemodialisis sebagian besar laki-laki sebesar 4180 orang laki-laki dan sisanya 2771 orang perempuan. Hal ini juga didukung penelitian sebelumnya yang dilakukan Ferry, Cerelia, Eko, (2016) yang menjelaskan bahwa dari 71 pasien yang dilakukan haemodialisis sebagian besar didominasi pasien laki-laki sebesar $61 \%$ dan sisanya $39 \%$ pasien perempuan. Dari perbandingan diatas dapat disimpulkan bahwa laki-laki lebih banyak dilakukan hemodialisis dibandingkan perempuan.

\section{Perubahan tekanan sistole dan diastole yang dilakukan hemodialisis}

Tekanan sistolik dan diastolik pada pasien yang dilakukan haemodialisis $A V$ Shunt sebagian besar kategori menetap dan menurun masing- masing sebesar 8 orang $(36.4 \%)$. Sedangkan pasien yang 
dilakukan haemodialisis jenis akses Dialisis Cephalica Femoral sebagian besar dalam kategori menetap sebesar 25 orang (56.8\%). Dari laporan tersebut dapat dijelaskan bahwa pasien yang telah dilakukan hemodialisis baik jenis $A V$ Shunt maupun akses Dialisis Cephalica Femoral hampir sama yaitu tidak mengalami perubahan tekanan sistolik dan diastolik.

Hal ini sesuai dengan penelitian sebelumnya yang dilakukan oleh Tayyebi, Samanehshasti, Tadrisi, Eynollahi, Mahdi, (2012) yang melaporkan bahwa pasien yang telah dilakukan haemodialisis tidak ada perbedaan yang signifikan antara tekanan darah dan indeks kecukupan dialysis. Penelitian serupa yang dilakukan Milad, Hamed, Milad and Masoumeh, (2016) yang menjelaskan bahwa tidak ada perbedaan signifikan secara statistik antara nilai tekanan darah dan kualitas hidup pada pasien pada hemodialisis.

\section{KESIMPULAN DAN SARAN}

Hasil penelitian menunjukkan bahwa usia pasien yang dilakukan hemodialisis adalah usia termuda 29 tahun dan tertua 77 tahun dan rentang usia terbanyak didapatkan pada usia $\geq 51$ tahun sebesar 59\%. Sebesar 57\% laki-laki lebih banyak mengalami gagal ginjal yang dilakukan hemodialisis dibandingkan jenis kelamin perempuan sebesar $43 \%$. Pasien yang dilakukan hemodialisis baik AV Shunt maupun akses Dialisis Cephalica Femoral sebagian besar tidak ada perubahan tekanan sistolik dan diastolik atau menetap. Saran yang diberikan pada hasil penelitian ini adalah sebaiknya Perawat di Ruang Hemodialisa tetap mewaspadai perubahan tekanan sistolik dan diastolik pada waktu pasien dilakukan hemodialisis, karena faktor penyebab perubahan tekanan sistolik dan diastolik pada pasien dengan gagal ginjal bermacam-macam. Selain itu, diperlukan penelitian yang lebih komplek tentang faktor-faktor yang mempengaruhi sistolik dan diastolic pada pasien yang dilakukan hemodialisis.

\section{DAFTAR RUJUKAN}

Ali Tayyebi, Samanehshasti, davod tadrisi, Behzad Eynollahi, Mahdi Sadeghi Sherme. 2012. Journal. The relationship between blood pressure and dialysis adequacy in dialysis patients. Iranian Journal of Critical Care Nursing, Spring 2012, Volume 5, Issue 1.

Ferry, Cerelia, Eko, 2016. Jurnal Elektronik. Profil pasien penyakit ginjal kronik yang dirawat di RSUP Prof. Dr. R. D. Jurnal eClinic (eCl), Volume 4, Nomor 1, Januari-Juni 2016.

Ferry Tigor P. Purba, Parlindungan Siregar, Ginova Nainggolan, Hamzah Shatri. 2014. Jurnal. Nilai Diagnostik Rerata Tekanan Darah Pre dan Post Hemodialisis pada Pasien yang Menjalani Hemodialisis Kronik. Jurnall Penyakit Dalam Indonesia Edisi Oktober 2014 Vol. 1, No. 2.

Hannie Qalbina Syaiful, Fadil Oenzil, Rudy Afriant, 2014. Jurnal. Hubungan Umur dan Lamanya Hemodialisis dengan Status Gizi pada Penderita Penyakit Ginjal Kronik yang menjalani Hemodialisis di RS. Dr. M. Djamil Padang. Jurnal Kesehatan Andalas; 3(3). http:// jurnal. fk. unand.ac.id

Ommy Agustriadi, Ketut Suwitra, Gde Raka Widiana, Wayan Sudhana, Jodi Sidharta Loekman, Yenny 
Kandarini. 2009. Jurnal. Hubungan antara Perubahan Volume darah Relative dengan Episode Hipotensi Intradialitik Selama Hemodialisis pada Gagal Ginjal Kronik. Jurnal Penyakit Dalam Universitas Udayana. Volume 10 Nomor 2 Mei 2009. ojs.unud.ac.id/ index.php/jim/article/download/38 $88 / 2883$

Perhimpunan Nefrologi Indonesia, 2015. 8th Report Of Indonesian Renal Registry 2015. Pernefri [internet]. 2015 [cited 2017 April 5]. Available from: www.pernefriinasn.org
Perhimpunan Nefrologi Indonesia, 2011. 4th Report Of Indonesian Renal Registry. Pernefri [internet]. 2011 [cited 2017 April 5]. Available from: www.pernefri-inasn.org

Smeltzer, Suzanne C. dan Bare, Brenda G, 2002, Buku Ajar Keperawatan Medikal Bedah Brunner dan Suddarth (Ed.8, Vol. 1,2), Alih bahasa oleh Agung Waluyo (dkk), EGC, Jakarta.

Syamsir, A \& Broto, H., 2007. Vita Health: Gagal Ginjal. Jakarta: Gramedia 